\title{
Periphytic and planktonic bacterial community structure in turbid and clear shallow lakes of the Pampean Plain (Argentina): a CARD-FISH approach
}

\author{
Laura María Sánchez ${ }^{1}$, María Romina Schiaffino ${ }^{1}$, Haydée Pizarro $^{1}$ \& ${\text { Irina } \text { Izaguirre }^{1}}^{1}$ \\ ${ }^{1}$ Departamento de Ecología, Genética y Evolución, IEGEBA (UBA-CONICET) \\ Facultad de Ciencias Exactas y Naturales, Universidad de Buenos Aires \\ Intendente Güiraldes 2160, Ciudad Universitaria, C1428EHA, Buenos Aires, Argentina \\ Corresponding author: María Laura Sánchez (laurasanchez@ege.fcen.uba.ar)
}

\begin{abstract}
Bacterioplankton and bacterioperiphyton composition was analyzed using the CARD-FISH technique in three shallow lakes of the Pampean Plain (Argentina) with contrasting regimes: clear vegetated, turbid due to phytoplankton and turbid inorganic, due to inorganic particles. We postulated that these differences would influence the proportion of the main bacterial groups both in periphyton and in plankton. The turbid lake due to phytoplankton presented the highest total abundances in both communities. Alphaproteobacteria was the dominant group in the three lakes in both communities. Redundancy analysis (RDA) evidenced that the bacterioplankton structure was different among lakes and mainly influenced by dissolved inorganic nitrogen and conductivity. On the other hand, for the bacterioperiphyton, RDA showed that bacterial group abundances increased with higher periphytic chlorophyll- $a$ values. In the clear lake the relative abundance of Betaproteobacteria and Cytophaga increased in the bacterioperiphyton towards the end of the colonization. Our study suggests that the lake regime (clear or turbid) influence the structure of bacterioplankton and bacterioperiphyton.
\end{abstract}

Keywords: bacterioperiphyton colonization, bacterioplankton, shallow lakes, CARD-FISH, Pampean Plain, Argentine.

\section{Estructura de las comunidades bacterianas perifíticas y planctónicas en lagunas turbias y claras de la llanura pampeana (Argentina): un enfoque aplicando CARD-FISH}

\begin{abstract}
RESUMEN. Se analizó la composición de bacterioplancton y bacterioperifiton utilizando la técnica de CARDFISH en tres lagunas de la llanura pampeana (Argentina) con regímenes contrastantes: laguna clara vegetada, laguna turbia por fitoplancton y laguna turbia inorgánica. Se postula que estas diferencias podrían influir sobre la proporción de los principales grupos bacterianos, tanto en el bacterioperifiton como en el bacterioplancton. La laguna turbia por fitoplancton presentó la mayor abundancia total de bacterias en ambas comunidades. El grupo de Alfaproteobacteria fue dominante en ambas comunidades y en las tres lagunas. El análisis de redundancia (RDA) evidenció que la estructura del bacterioplancton fue diferente entre las lagunas y estuvo principalmente influenciado por el nitrógeno inorgánico disuelto y la conductividad. Por otra parte, para el bacterioperifiton el RDA mostró que la abundancia de los grupos bacterianos se incrementó a mayores valores de clorofila- $a$ perifítica. En la laguna clara las abundancias relativas de los grupos Betaproteobacteria y Citofaga aumentaron hacia el final del período de estudio. Este estudio sugiere que el régimen (claro o turbio) de cada cuerpo de agua influye sobre la estructura del bacterioplancton y bacterioperifiton.
\end{abstract}

Palabras clave: colonización del bacterioperifiton, bacterioplancton, lagunas, CARD-FISH, llanura pampeana Argentina.

\section{INTRODUCTION}

Different bacterial taxonomic groups, which differ in their trophic strategies and physiological capabilities, have been reported for both freshwater and marine environments (e.g., Alonso Sáez \& Gasol 2007; Newton et al., 2011). Betaproteobacteria, well represented in freshwaters are characterized as opportu-

Corresponding editor: Beatriz Modenutti 
nistic in nutrient-enriched conditions (Glöckner et al., 1999; Newton et al., 2011; Salcher, 2014). Actinobacteria, whose small cell sizes confer them an advantage under high predation pressure and UV radiation (Pernthaler et al., 2001; Warnecke et al., 2005) and Gammaproteobacteria, adapted to grow under high-nutrient concentrations (Newton et al., 2011), are also successful in freshwater systems. In contrast, Alphaproteobacteria are more abundant in marine than in freshwater ecosystems (Methé et al., 1998; Glöckner et al., 1999). Finally, a large group of bacteria constituted by Cytophaga-FlavobacteriumBacteroidetes (hereinafter Cytophaga), which are important in biopolymer degradation, has also been reported in freshwater systems (Lemarchand et al., 2006).

These bacterial groups can be represented both in bacterioplankton and bacterioperiphyton (bacterial component of the biofilms), and the proportion of the different groups may exhibit temporal changes. In the bacterioplankton these changes have been mainly studied in relation to fluctuations in algal biomass, nutrient and grazers (e.g., Posch et al., 2007; Salcher, 2014), whereas the succession in bacterioperiphyton community has been poorly analyzed. In freshwater biofilms, the relative proportion of the main bacterial groups changes according to environmental variables (Glöckner et al., 2000), being identified Cytophaga as pioneers and Gammaproteobacteria and Betaproteobacteria dominant in later stages of the succession (Pohlon et al., 2010). On the other hand, the nutritional status of the lake has influence on the bacterial abundance in the biofilms. It has been reported that in nutrient-enriched lakes, bacteria of the biofilms tend to be more abundant and form a thicker matrix than under poor nutrient conditions; however, the influence of the different nutrients on the characteristics of bacterioperiphyton is still unclear (Stoodley et al., 2000).

The Pampa Plain (Argentina) contains thousands of shallow lakes, thus constituting a typical lacustrine wetland (Brinson, 2004). Due to the intensive agriculture that takes place in this region, nowadays most of these shallow lakes are in a turbid state, showing high phytoplankton biomass (hereinafter phytoplankton turbid shallow lakes) (Quirós et al., 2002, 2006). Nevertheless, some of them still present a clear vegetated state with high transparency and submerged vegetation (clear shallow lakes). These two types of shallow lakes fit well with the two alternative equilibria stable states described by Scheffer et al. (1993). Recently, Scheffer (2009) postulated the concept of regime instead of alternative stable states, since shallow lakes are in permanent slow change, and called 'shift regime' to the transition from one regime to another. In addition, a third type of water body is also present in this region -inorganic turbid shallow lakes-, characterised by high turbidity associated with high concentrations of inorganic suspended particles from allochthonous sources resulting from the direct human impact on their drainage basin (Quirós et al., 2002; Allende et al., 2009). The variety of shallow lakes in this region constitutes an interesting scenario to analyze the structure of the microbial communities. In particular, the contrasting optical properties of these water systems (Pérez et al., 2010) have been found to influence the phytoplankton structure (Allende et al., 2009; Izaguirre et al., 2012) and the relative importance of phytoplankton $v s$ periphyton communities (Sánchez et al., 2010, 2013). Silvoso et al. (2010) analyzed the relative abundances of the picoplankton components, including bacterioplankton, in shallow lakes of this region and found that clear vegetated lakes exhibit similar picophytoplankton/bacterioplankton ratios but no clear trend in turbid lakes. In the same region, Llames et al. (2013) studied the influence of environmental factors on bacterioplankton community composition by using molecular techniques, and found that the regime of the systems plays a major role in structuring the bacterial community. These authors suggested that the patterns observed in each type of shallow lake are probably driven by differences in the nature of the predominant organic matter sources and pools (macrophytes, phytoplankton and terrestrial organic carbon). Nevertheless, none of these studies were focused on both bacterioplankton and bacterioperiphyton. The incorporation of the bacterioperiphyton community is essential to a better understanding of the aquatic bacteria ecology since shallow lakes have a well-developed littoral zone with an important growth of the attached communities (Sánchez et al., 2013).

In this study we analyzed, applying Catalyzed Reported Deposition Fluorescent in situ Hybridization technique (CARD-FISH), the structure of bacterioplankton and bacterioperiphyton in shallow lakes of the Pampa Plain (Argentina) with different regimes (clear vegetated, phytoplankton turbid and inorganic turbid). Moreover, we identified, by means of multivariate analyses, which environmental variables influenced the bacterial composition in each community. We also experimentally analyzed the changes in bacterioperiphyton colonization in each shallow lake.

\section{MATERIALS AND METHODS}

\section{Study area}

We studied three shallow lakes, which differ in their regime: el Triunfo, a clear vegetated shallow lake with abundant submerged vegetation (mainly Ceratophyllum 
demersum) and low phytoplankton abundances ( $\left.35^{\circ} 51^{\prime} \mathrm{S}, 57^{\circ} 52^{\prime} \mathrm{W}\right)$; El Burro, a turbid shallow lake with high abundances of phytoplankton $\left(35^{\circ} 42^{\prime} \mathrm{S}\right.$, $57^{\circ} 55^{\prime} \mathrm{W}$ ) and Yalca, an inorganic turbid shallow lake with high amounts of suspended solids $\left(35^{\circ} 35^{\prime} \mathrm{S}\right.$, $\left.57^{\circ} 55^{\prime} \mathrm{W}\right)$. The studies were carried out from October 22 to November $1^{\text {st }} 2010$.

\section{Experimental design}

Bacterioperiphyton was studied with artificial substrata placed near the surface in the littoral zone of each shallow lake, using an acrylic device with 40 artificial substrata. Artificial substrata consisted in polycarbonate pieces $1 \mathrm{~mm}$ thick and $2 \mathrm{~cm}$ wide $\mathrm{x} 7.5 \mathrm{~cm}$ long. At least two devices with artificial substrata were placed in each lake. The colonization experiments were run along 3 weeks in all lakes. In El Burro and Yalca, bacterioperiphyton samples were taken at $3(\mathrm{t} 1), 10(\mathrm{t} 2)$ and 20 days (t3), whereas in El Triunfo, samples were taken at $3(\mathrm{t} 1), 7(\mathrm{t} 2), 10(\mathrm{t} 3)$ and 17 days (t4). Bacterioplankton samples were collected in a plastic bottle simultaneously in all lakes throughout the experiment. All samples were obtained by duplicate. Bacterioplankton was pre-filtered through a $55-\mu \mathrm{m}$ pore net to exclude zooplankton. All samples were fixed with formaldehyde $10 \%$ final concentration. The artificial substrata were preserved in dark and cold conditions inside hermetic bags during their transport to the laboratory where the attached material was scraped off with a sharp piece of polycarbonate, suspended in milliQ water and fixed in the same way as bacterioplankton samples.

\section{Physical and chemical variables}

To characterize each shallow lake, $\mathrm{pH}$, conductivity and temperature were measured in situ on each sampling date with a portable sensor HORIBA D-54E (Japan), whereas dissolved oxygen (DO) was measured with a portable sensor HANNA HI 9146 (Hanna Instruments, USA).

Downward irradiance profiles were obtained around noon using a USB2000 (Ocean Optics, Florida, USA) spectroradiometer attached to an optical fiber, and a teflon diffuser, following the same methodology described in Sánchez et al. (2013). Vertical diffuse attenuation coefficients for PAR (Kd $\left.\mathrm{PAR}_{\mathrm{P}}\right)$ were determined from the slope of the linear regression of the natural logarithm of downward irradiance profiles $v s$. depth. Additionally, we measured the Secchi depth of each shallow lake.

Main dissolved and total nutrients were determined in duplicate on each sampling date. Sub-superficial samples were taken in each shallow lake. Nitrate + nitrite (cadmium reduction method), soluble reactive phosphorous (SRP) (ascorbic acid method) and ammonium (salicylate method) were analyzed with a HACH DR/2010 spectrophotometer (HACH Company, USA) using the corresponding kits of $\mathrm{HACH}$ reagents. Dissolved inorganic nitrogen (DIN) was calculated as nitrate + nitrite + ammonium. Total nitrogen (TN) and total phosphorus (TP) concentrations were determined subsequently to the digestion with boric acid and potassium persulphate, following the methodology described in APHA (2005) using the same HACH kits as those used for dissolved nutrients.

Chlorophyll- $a$ concentration (Chl- $a$ ) of phytoplankton and periphyton communities was determined in duplicate on each sampling date. The samples were filtered through Whatman GF/F filters. Chl- $a$ was estimated spectrophotometrically using hot ethanol $\left(60-70^{\circ} \mathrm{C}\right)$ (Marker et al., 1980), following the formulae described in Lorenzen (1967).

\section{Catalyzed reported deposition fluorescent in situ hybridization (CARD-FISH)}

\section{Bacterioplankton}

The CARD-FISH technique was performed following the methodology described in Pernthaler et al. (2004). Each sample was homogenized using a vortex Velp Scientifica (Usmate, Italy) and then a known volume was filtered through a $0.2-\mu \mathrm{m}$ pore-size polycarbonate white filter and preserved at $-20^{\circ} \mathrm{C}$.

Whole-cell in situ hybridizations of polycarbonate filter sections were performed as described by Pernthaler et al. (2002) and Sekar et al. (2003), using the following oligonucleotide probes: EUB338-II-III (a mix of EUB338, EUB338(II) and EUB338(III)), to target most Eubacteria, including Verrucomicrobia and Planctomycetes (Amann et al., 1990; Daims et al., 1999) -being this probe useful as a control to analyze the hybridization percentage in relation to the total 4',6diamidino-2-phenylindole (DAPI)-stained bacterial density-; ALF968, specific for Alphaproteobacteria (Amann \& Fuchs, 2008); BET42a, to target Betaproteobacteria (Manz et al., 1992); GAM42a, for Gammaproteobacteria (Manz et al., 1992); CF319a, to target Cytophaga (Manz et al., 1996), and HGC69a for Actinobacteria (Amann et al., 1995). Probes were supplied by Thermo Electron Corporation (Waltham, MA, USA) with an aminolink (C6) at the $5^{\prime}$ end, ligated with a horseradish peroxidase enzyme (Urdea et al., 1988). Each probe was incubated in the corresponding hybridization buffer. Competitor probes, which are specific probes that avoid miss-match in the hybridization process between both bacterial groups, were added to BET42a and GAM42a. Hybridizations were run overnight at $35^{\circ} \mathrm{C}$. After hybridization, the signal was amplified with Alexa 488-labeled tyramide 
and counter-stained with immersion oil containing DAPI (Vecta Shield, USA). Filter pieces were mounted on a slide and observed by epifluorescence microscopy (Olympus BX40F4, Japan) under blue light and UV excitation. Because the probe EUB338-II-III does not give total hybridisable bacterial abundances in all environments, the contribution of each bacterial group to the prokaryotic community was calculated as a percentage of DAPI counts (relative abundance or hybridization percentage).

\section{Bacterioperiphyton}

The attached material was scraped off carefully, suspended in milliQ water and fixed. The bacterioperiphyton was then mechanically separated with a vortex and subsequently subjected to the action of a sonicator Sonics (Newtown, USA) to obtain a complete homogenization of the samples (Velji \& Albright, 1993). Then, the samples were filtered through a $0.2-\mu \mathrm{m}$ pore-size polycarbonate white membrane. The hybridization steps were identical to those previously described for bacterioplankton and were performed simultaneously.

\section{Statistical analyses}

To analyze variations over time, we performed repeated measures ANOVA (RM ANOVA), using bacterial groups (Alphaproteobacteria, Betaproteobacteria, Gammaproteobacteria, Actinobacteria, Cytophaga) and time as factors. Two-way ANOVA were performed at final time to compare abundances of the different bacterial groups among lakes. Before each analysis, Shapiro-Wilk and Levene tests were run to check data for normality and homocedasticity. Whenever the data did not confirm the assumptions, the values were transformed as necessary. RM ANOVA was run with SPSS 17.0 (USA). To compare relative abundances among different groups at the end of the study, we performed chi-squared contingency tables with the following factors: lake (El Triunfo, Yalca and El Burro) and bacterial groups (Alphaproteobacteria, Betaproteobacteria, Gammaproteobacteria, Actinobacteria, Cytophaga). We also analyzed differences in the hybridization percentage of bacterial groups among the three shallow lakes between bacterioperiphyton and bacterioplankton at the end of the study with chisquared contingency tables using Infostat (Argentina).

In addition, to analyze relations among environmental variables and bacterial composition, we performed multivariate analyzes with planktonic and periphytic bacteria using the software CANOCO (Ter Braak, 1986). All data of absolute abundances were included in the analysis. To identify the environmental variables controlling the abundances of the bacterial groups, we carried out a redundancy analysis (RDA), after the application of a detrended correspondence analysis (DCA) with the matrix of bacterioplankton and bacterioperiphyton abundances, which indicated a linear response of the data (Ter Braak \& Smilauer, 2002).

\section{RESULTS}

\section{Physical and chemical variables}

Table 1 indicates the results of the environmental variables measured along the study period. The clear vegetated shallow lake showed higher $\mathrm{pH}$ and conductivity values than the turbid ones. The turbid lakes did not differ in their $\mathrm{pH}$ values. Yalca presented the lowest values of conductivity. The lowest DIN concentrations were found in the clear vegetated (El Triunfo) and in the inorganic turbid (Yalca) shallow lakes. Although SRP was relatively high in the three shallow lakes, their values were highest in El Triunfo. TN was highest in El Triunfo and lowest in Yalca and TP showed no variations among the lakes. According to their optical variables (Secchi depth and $\mathrm{Kd}_{\mathrm{PAR}}$ ), El Burro and Yalca showed higher light limitation than El Triunfo (Table 1).

\section{Bacterioplankton}

The hybridization percentage of EUB338-II-III (Eubacteria) on total DAPI-stained bacteria varied among the lakes. El Triunfo exhibited the highest hybridization percentages (average 60.6\%), intermediate values were observed in Yalca (average 47.6\%), whereas El Burro showed the lowest values (average $29.5 \%)$.

Alphaproteobacteria was the most abundant group in the three shallow lakes and presented the highest hybridization percentage (average values: $46.5 \%$ in $\mathrm{El}$ Triunfo, $31 \%$ in El Burro and $54.2 \%$ in Yalca). The second most important group in El Triunfo was Betaproteobacteria (34.6\%), whereas Betaproteobacteria and Actinobacteria were the second most important groups in the other two lakes $(13.7 \%$ and $13.9 \%$ in Yalca; $8.8 \%$ and $7.4 \%$ in El Burro, respectively) (Figs. 1a-1c). Actinobacteria and Cytophaga showed intermediate abundances in El Triunfo (Fig. 1a) and Gammaproteobacteria was the least represented group in the three lakes.

Total bacteria attained the highest abundances in $\mathrm{El}$ Burro (two-way ANOVA factors: lake and bacterial groups, simple effect $P<0.0001$ ) and the lowest in El Triunfo (Fig 1a).

At the end of the sampling period we found significant differences in the abundance of bacterial 
Table 1. Environmental variables measured in the three shallow lakes studied. Maximum and minimum values recorded throughout the study period are shown. DO: dissolved oxygen, DIN: dissolved inorganic nitrogen, SRP: soluble reactive phosphorus, TN: total nitrogen, TP: total phosphorus, KdPAR: vertical diffuse attenuation coefficients for PAR.

\begin{tabular}{lccc}
\hline Variable & $\begin{array}{c}\text { El Triunfo } \\
\text { (clear vegetated) }\end{array}$ & $\begin{array}{c}\text { El Burro } \\
\text { (phytoplankton turbid) }\end{array}$ & $\begin{array}{c}\text { Yalca } \\
\text { (inorganic turbid) }\end{array}$ \\
\hline pH & $9.4-9.8$ & $8.4-8.8$ & $8.4-8.8$ \\
Conductivity $\left(\mu \mathrm{S} \mathrm{cm}^{-1}\right)$ & $1108-1480$ & $961-1300$ & $428-588$ \\
DO $\left(\mathrm{mg} \mathrm{L}^{-1}\right)$ & $7.3-10.2$ & $8.6-12.3$ & $8.4-10.4$ \\
Temperature $\left({ }^{\circ} \mathrm{C}\right)$ & $15.9-25.0$ & $17.2-23.0$ & $17.4-27.4$ \\
DIN $\left(\mu \mathrm{g} \mathrm{L}^{-1}\right)$ & $15-75$ & $375-440$ & $25-65$ \\
$\mathrm{SRP}\left(\mu \mathrm{g} \mathrm{L}^{-1}\right)$ & $110-355$ & $90-245$ & $105-255$ \\
$\mathrm{TN}\left(\mu \mathrm{g} \mathrm{L}^{-1}\right)$ & $8950-10150$ & $1390-7490$ & $3680-7060$ \\
TP $\left(\mu \mathrm{g} \mathrm{L}^{-1}\right)$ & $400-530$ & $420-550$ & $420-490$ \\
Secchi $\left(\mathrm{cm}^{-1}\right)$ & $70-88$ & $16-16.5$ & $12-16.5$ \\
Kd & $3.7-5.4$ & $8.6-16.7$ & $11.4-26.1$ \\
\hline
\end{tabular}

groups among the three lakes (contingency table $P<$ $0.0001)$. However, in each lake we did not detect differences in the abundance of each bacterial group throughout the period studied.

Results of RDA based on the absolute abundances of each planktonic bacterial group and environmental variables are shown in Fig. 2. The first two axes accounted for $92.5 \%$ of the variance (axis 1: 69.5\%, axis 2: $23.0 \%$ ). The Monte Carlo's test indicated that the abiotic factors were significantly correlated with the first canonical axis $(P<0.01)$, and was also significant with all canonical axes $(P<0.05)$. The following variables were statistically significant: DIN $(P<$ $0.005)$, conductivity $(P<0.005)$ and DO $(P<0.05)$ (solid arrows in Fig. 2). The first axis was mainly defined by DIN and phytoplanktonic Chl- $a$ (correlation coefficients: 0.89 and 0.85 respectively) and the second axis was mainly correlated with conductivity and $\mathrm{Kd}_{\mathrm{PAR}}$ (correlation coefficients: 0.87 and -0.79 respectively). This analysis showed an almost invariable composition of the planktonic bacterial community throughout time. Remarkably, RDA evidenced three well-separated groups of sites corresponding to each shallow lake (dotted lines in Fig. 2) based on their bacterioplankton composition and the main environmental variables. This analysis also showed that the samples corresponding to the phytoplankton turbid lake were associated with higher phytoplankton Chl- $a$, DIN and DO values. On the other hand, samples corresponding to El Triunfo were related with higher SRP values, whereas those of Yalca were ordered to lower conductivity and higher KdPAR values. Regarding to bacterial groups, Alphaproteobacteria and Actinobacteria were ordered to higher values of $\mathrm{Kd}_{\mathrm{PAR}}$ and DO and were more related with samples corresponding to the inorganic turbid lake. Cytophaga and Betaproteobacteria were more associated with conductivity and Gammaproteobacteria with higher values of DIN and Chl- $a$. These three bacterial groups were more related with the phytoplankton turbid lake.

\section{Bacterioperiphyton}

The Eubacteria hybridization percentages were similar in El Triunfo and El Burro (average values 77\%, and $79.6 \%$ respectively), whereas Yalca showed the lowest values (65.4\% on average).

Bacterioperiphyton was mainly represented by Alphaproteobacteria in the three shallow lakes all over the studied period (Fig. 3). On average, the second largest group was Betaproteobacteria in El Triunfo and Yalca (hybridization percentage $22.6 \%$ and $14.11 \%$ respectively), and Gammaproteobacteria in El Burro (hybridization percentage 24.6\%). Actinobacteria, whose hybridization percentages varied between $1.3 \%$ and $2.2 \%$, was the least represented group in the three lakes studied (Fig. 3).

Analyzing the variations through the time, we detected an increase in the hybridization percentage of Alphaproteobacteria from $55.8 \%$ to $60.2 \%$ (RM ANOVA factor: time $P<0.01)$ for El Triunfo. In this lake, Gammaproteobacteria was the second group in importance at the beginning of the colonization period, decreasing towards the end (from 46.2 to $9.2 \%$ ). This group was replaced by Cytophaga (which increased from 6.6 to 19.7\%) and Betaproteobacteria (which oscillated between 22.1 and 31.8\%) (Fig. 3a).

In El Burro we did not observe differences among the abundances of the different bacterial groups at the beginning of colonization. However, after that Alphaproteobacteria showed a significant increase (RM ANOVA factor: time $P<0.0001$ ) and then 

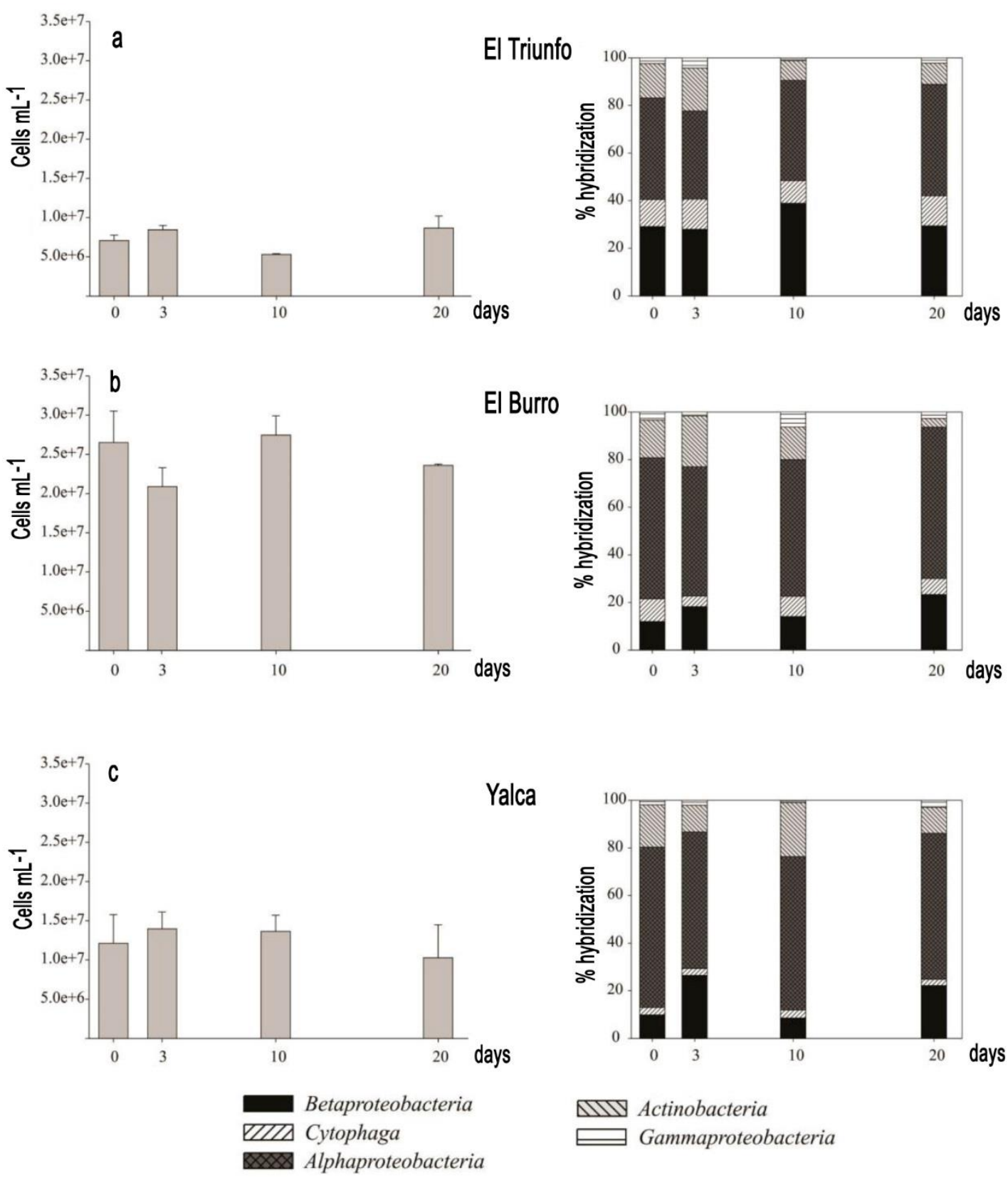

Figure 1. Bacterioplankton variation throughout time in the three shallow lakes studied. Left panel: total bacteria abundances, bars represent \pm standard deviation $(\mathrm{n}=2)$. Right panel: hybridization percentage of each probe regarding total DAPI-stained bacteria.

remained constant until the end of the experiment (Fig. $3 b)$.

In Yalca, Alphaproteobacteria showed an increase in their abundances with time (RM ANOVA factor: time $P<0.01$; factor: bacterial group $P<0.02$ ). The hybridization percentage oscillated between $53.1 \%$ at the beginning ( $\mathrm{t} 1$ ) and $56.2 \%$ at the end (t3). Furthermore, in this inorganic-turbid lake the abundances of Betaproteobacteria and Cytophaga increased towards the end of the study period (Fig. 3c).

At the end of the study El Burro showed significantly higher abundances of Alphaproteobacteria and Gammaproteobacteria than the other two lakes (two-way ANOVA factors: lake and bacterial group, simple effects $P<0.0001 ; P<0.03$ respectively). Contrarily, no significant differences 


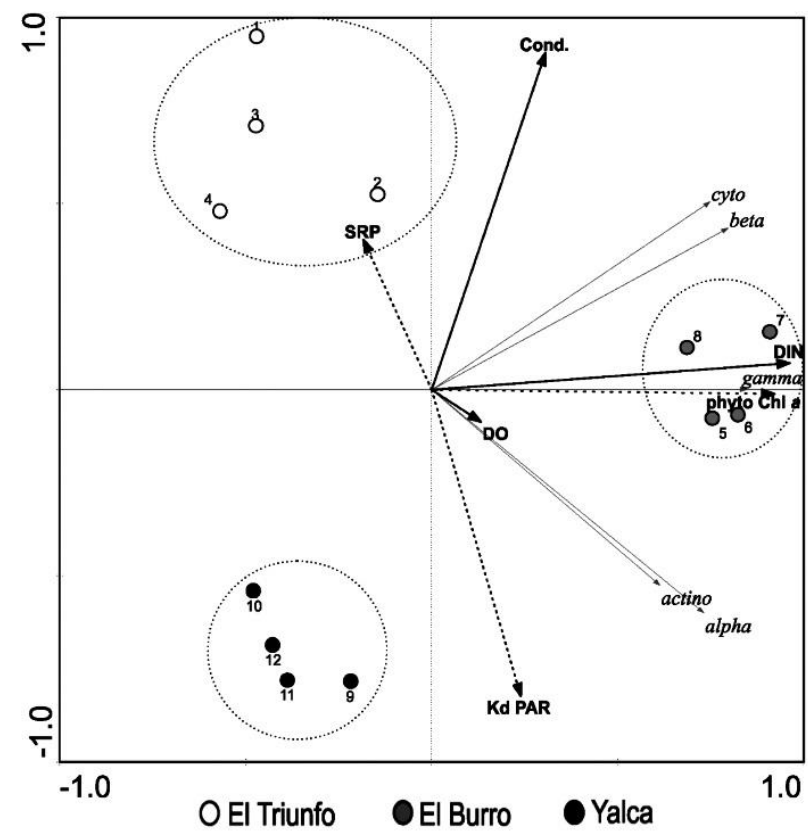

Figure 2. Triplot corresponding to the redundancy analysis (first and second axis) based on the abundance of the different bacterioplankton groups and environmental variables. Samples 1-4: El Triunfo (samples taken at t0, $\mathrm{t} 1, \mathrm{t} 2$ and $\mathrm{t} 3$ respectively); samples 5-8: El Burro (samples taken at $\mathrm{t} 0, \mathrm{t} 1, \mathrm{t} 2$ and $\mathrm{t} 3$ respectively); samples 9-12: Yalca (samples taken at $\mathrm{t} 0, \mathrm{t} 1, \mathrm{t} 2$ and $\mathrm{t} 3$ respectively). Solid and dotted arrows indicate significant and non-significant environmental variables $(P<0.05)$, respectively. Cond: conductivity, DO: dissolved oxygen, DIN: dissolved inorganic nitrogen, SRP: soluble reactive phosphorus, Kd PAR: vertical diffuse attenuation coefficients for PAR, phyto Chl $a$ : phytoplanktonic chlorophyll- $a$. The names of the bacterial groups are abbreviated.

were recorded among the other bacterial groups. We also found differences among the lakes in the hybridization percentage of the bacterial groups at the end of the study (Contingency table, $P<0.0001$ ). These differences were due to changes in the contribution of the subdominant groups in each lake.

The results of the RDA based on the abundance of bacterioperiphyton groups and environmental variables are shown in Fig. 4. The first two axes accounted for $99.6 \%$ of the variance (first axis: $96.1 \%$, second axis: $3.5 \%$ ). Monte Carlo's test indicated that abiotic factors were significantly correlated with the first canonical axis $(P=0.03)$ and with all canonical axes $(P=0.03)$. Environmental variables that resulted significant were periphytic Chl- $a(P=0.008)$ and DO $(P=0.04)$. The most important variables in the first axis were periphytic Chl- $a$ and DIN (correlation coefficients: 0.97 and 0.74 respectively), whereas the most important variables in the second axis were SRP and conductivity (correlation coefficients: -0.61 and 0.48 respectively). The ordination of the samples corresponding to El Burro evidenced a temporal trend, which was related with an increase in the relative abundance of Actinobacteria, Betaproteobacteria and Gammaproteobacteria during the colonization process. Concomitantly, these samples were ordered along an increasing gradient of periphyton Chl- $a$. On the other hand, samples of Yalca were placed following a decrease in the relative abundance of Alphaproteobacteria during colonization. Contrarily, for El Triunfo, no temporal effect was detected, since almost all samples were ordered together, with the exception of samples of $t 4$ that was plotted separately in coincidence with an increase in the relative abundance of Betaproteobacteria.

Finally, we compared the hybridization percentage of the different groups between bacterioperiphyton and bacterioplankton among the three shallow lakes at the end of the study, and we observed that the bacterial composition varied between both communities (contingency table, $P<0.0001$ ). Notwithstanding, Alphaproteobacteria was dominant in both communities and in the three studied lakes; Actinobacteria was more important in bacterioplankton and Gammaproteobacteria in bacterioperiphyton (Fig. 5).

\section{DISCUSSION}

Our results showed that each shallow lake (clear, phytoplankton turbid and inorganic turbid) has noticeable differences in the structure of their bacterioperiphyton and, not so markedly, in the bacterioplankton. Relative abundances of each bacterial group changed in the periphyton during the succession, reaching a different mature final stage in each lake. These differences could be attributed to the different regime but also to the inner conditions of the matrix and to the biological interactions that occur within it; as the dissolved organic matter production by epiphytic algae that could be degraded by bacteria generating mutual benefit (Hempel et al., 2008). On the other hand, differences in bacterioplankton were associated with variations in the relative abundances of the subdominant groups in each lake, as was observed in the higher contribution of Actinobacteria in the turbid lakes, and particularly in the higher proportion of Gammaproteobacteria, Betaproteobacteria and Cytophaga in the phytoplankton turbid one. These differences are likely due to the contrasting optical and nutrient conditions of these lakes. Our results are in line with those of Van der Gucht et al. (2005), who analyzed the bacterioplankton in eutrophic and hypertrophic clear and turbid shallow lakes, finding a distinctive 

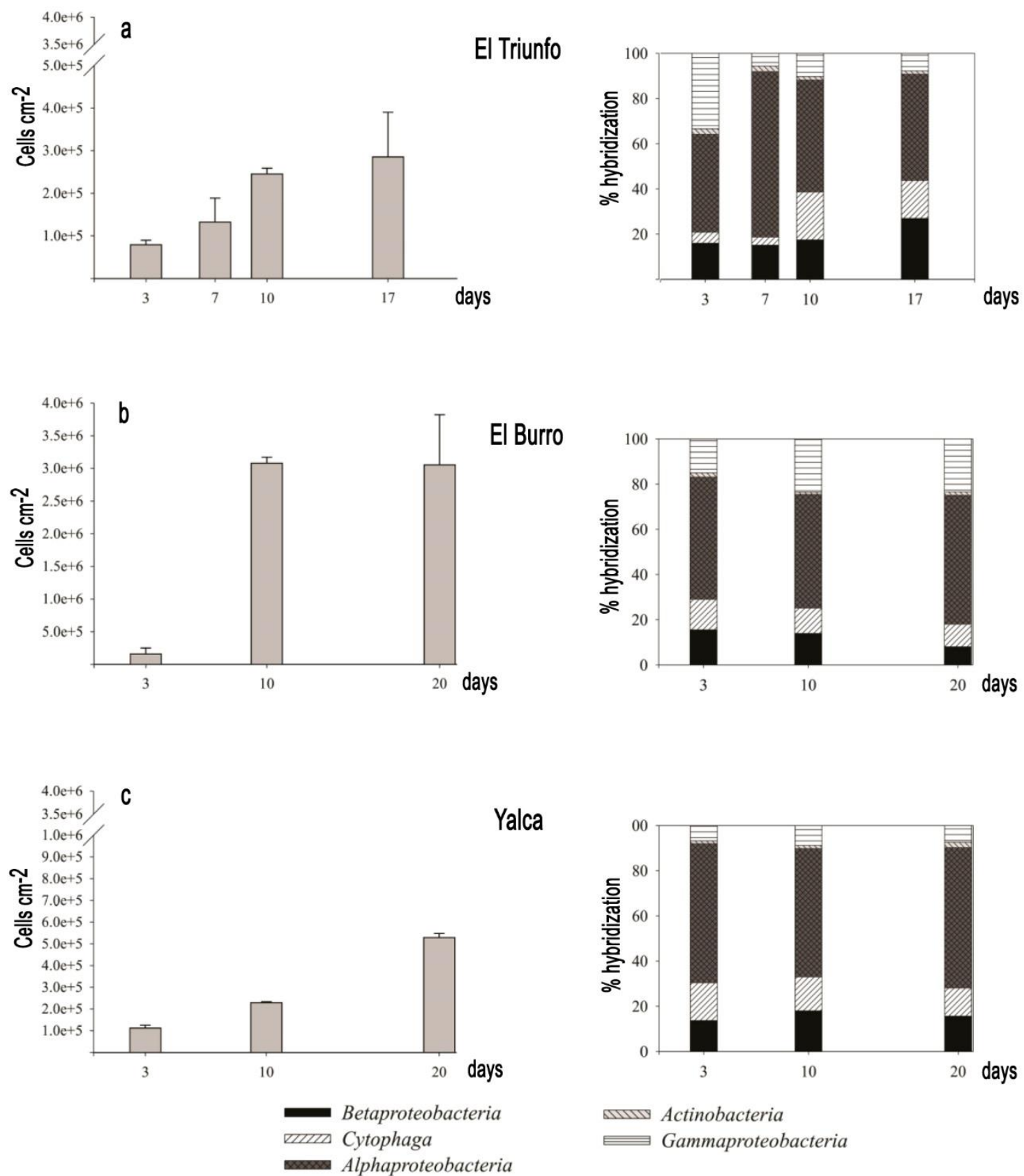

Figure 3. Bacterioperiphyton variation throughout time in the three shallow lakes studied. Left panel: total bacterial abundances, bars represent \pm standard deviation $(n=2)$. Right panel: hybridization percentage of each probe regarding total DAPI-stained bacteria.

bacterial community in each one of the lakes, and partly attributed these differences to the lake states (clear or turbid). Furthermore, within each shallow lake, the comparison between bacterioplankton and bacterioperiphyton showed that both communities differed in their bacterial composition.

Some of the most important physical and chemical factors that regulate bacterial assemblages are tempe- rature, UV radiation, organic matter, and nutrient concentrations (Logue et al., 2008). In our study, the bacterioplankton was more influenced by DIN and conductivity; coincidently, these variables showed the highest range of variation among the studied shallow lakes. In particular, we recorded low levels of DIN in the clear vegetated lake and in the inorganic turbid one. The presence of submerged macrophytes in the clear 


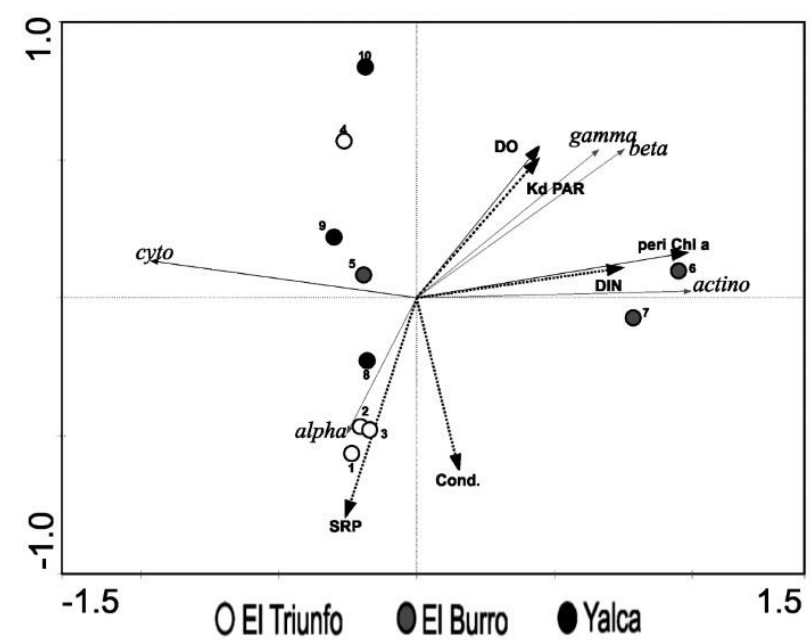

Figure 4. Redundancy analysis (first and second axis) triplot Analysis based on the abundance of the different bacterioperiphytic groups and environmental variables. Samples1-4: E1 Triunfo (samples taken at t1, t2, t3 and t4 respectively); samples 5-7: El Burro (samples taken at $\mathrm{t}$, t2 and t3 respectively); samples 8-10: Yalca (samples taken at $\mathrm{t} 1, \mathrm{t} 2$ and $\mathrm{t} 3$ respectively). Solid and dotted arrows indicate significant and non-significant environmental variables $(P<0.05)$, respectively. Cond: conductivity, DO: dissolved oxygen, DIN: dissolved inorganic nitrogen, SRP: soluble reactive phosphorus, Kd PAR: vertical diffuse attenuation coefficients for PAR, peri Chl- $a$ : periphytic chlorophyll- $a$. The names of the bacterial groups are abbreviated.

shallow lake could explain the low availability of DIN; low nutrient levels in vegetation stands may be due to uptake by plants but also to uptake by periphyton and denitrification (Villar et al., 1998; Scheffer, 1998). In Yalca, the lower values of DIN, conductivity and turbidity in comparison with those reported in previous studies (Allende et al., 2009) could be tied to a dilution effect due to an increase in the hydrometric level of the shallow lake (personal observation). Several physical and chemical factors (such as light, temperature and nutrients) could regulate bacterial growth; in particular, temporal nitrogen depletion might favour oligotrophic ultramicrobacteria such as LD12 Alphaproteobacteria, the most abundant and ubiquitous freshwater bacterial lineages (Salcher, 2014).

Interestingly, we observed the dominance of Alphaproteobacteria in the three shallow lakes and in the two communities analyzed. Recently, Newton et al. (2011) have pointed out that the genomic and lifestyle plasticity of Alphaproteobacteria allows them to live in a great variety of habitats. Moreover, De Figueiredo et al. (2010) have described Alphaproteobacteria as a group related with high values of temperature, conductivity, $\mathrm{pH}$ and SRP in a eutrophic lake. In another study that includes several lakes with different limnological characteristics, Salcher et al. (2011) found a sub-clade of Alphaproteobacteria (LD12) that was highly abundant in all the studied water bodies. Furthermore, and in agreement with our results, in a study about successional changes of bacterial community on biofilms in rivers, Alphaproteobacteria was the most abundant group towards the last succession stages (Lupini et al., 2011).

Regarding bacterioplankton, Betaproteobacteria was the second most abundant group in importance in the three shallow lakes, together with Actinobacteria in the turbid ones. Betaproteobacteria have the ability to take advantage under eutrophic conditions, as was demonstrated by Bertoni et al. (2008), in an experiment with nutrient addition in oligotrophic lakes. These authors proposed that the successful of this group was associated with its opportunistic ecological strategy. Moreover, although Gammaproteobacteria seem to prefer lakes with high nutrient concentrations, when nutrients were added, Betaproteobacteria outcompete the other groups. In agreement with these results Betaproteobacteria were more abundant than Gammaproteobacteria in the eutrophic shallow lakes here studied.

In the bacterioperiphyton, even though Alphaproteobacteria were also dominant, an increase in the relative abundances of Betaproteobacteria and Cytophaga was observed towards the end of the colonization period in the clear lake and, less evidently, in the inorganic turbid one. In an experimental study, Šimek et al. (2006) reported planktonic Betaproteobacteria as an opportunistic and fast-growing group. This group may show a similar growth strategy in the bacterioperiphyton, which could explain the increase in its relative abundance. On the other hand, Cytophaga have been described as principal component of biofilms in several studies. These bacteria degrade organic molecules of high molecular weight (Hempel et al., 2008), thus being best represented in mature steps of the colonization. In another study on biofilm colonization, Araya et al. (2003) found that Betaproteobacteria and Cytophaga dominated during the whole analyzed period. The results of the multivariate analysis for bacterioperiphyton suggest a positive relationship between the abundance of most of the analyzed bacterial groups (Actinobacteria, Gammaproteobacteria, Betaproteobacteria) and the autotrophic fraction of the biofilm (evaluated as Chl-a). This tendency was particularly evident in the shallow lake El Burro. However, specifically for Cytophaga we observed an opposite trend, since higher values of this group were associated with lower periphytic Chl- $a$. 


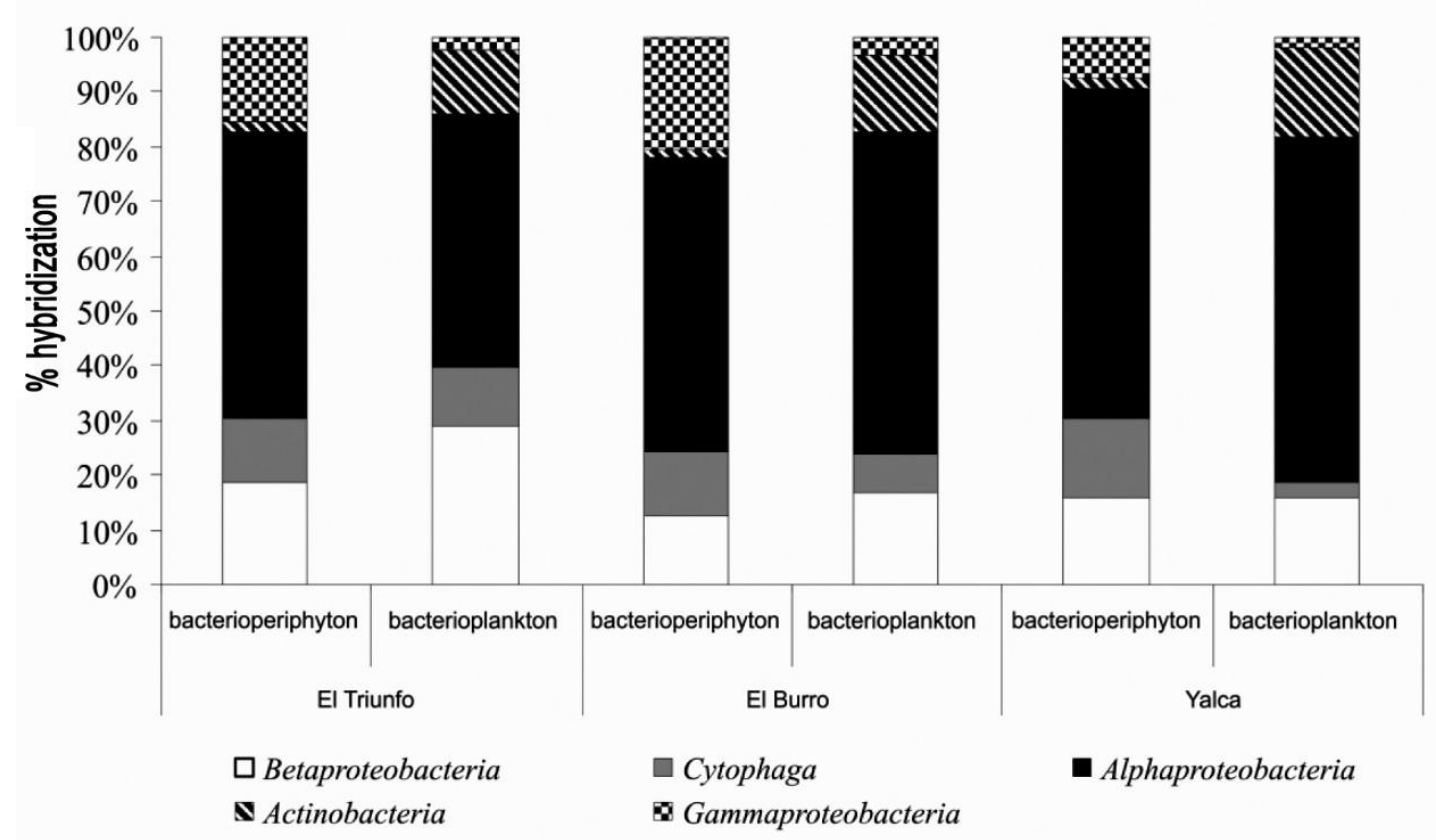

Figure 5. Hybridization percentage on the final sampling occasion, in each shallow lake and in both communities.

Comparing the three types of shallow lakes here studied, the phytoplankton turbid one (El Burro) presented the highest bacterial abundances, dominated by Alphaproteobacteria, in both bacterioplankton and bacterioperiphyton. A previous study on the picoplankton of shallow lakes of the same region (Silvoso et al., 2010) also showed that bacterioplankton abundance was higher in phytoplankton turbid lakes than in clear or inorganic turbid ones. In the same study, a positive correlation was found between bacterioplankton abundance and phytoplankton Chl- $a$, suggesting commensalistic interactions between phytoplankton and bacteria, since the labile organic matter produced by phytoplankton would be the main $\mathrm{C}$ source for bacterial growth in shallow lakes with high phytoplankton biomass. Recently, Llames et al. (2013) proposed that the differences in optical characteristics in the shallow lakes of the same region are related to differences in the main organic matter pools and thus, in the substrata for the different planktonic bacterial groups in each type of shallow lake. According to these authors, in clear vegetated lakes, the abundant macrophytes provide mainly organic carbon for bacteria, while in phytoplankton turbid lakes algae would be the principal source of organic matter. In this sense, the highest bacterial abundances both in plankton and periphyton observed in the phytoplankton turbid lake in our study are probably related to a higher amount of labile DOC in this lake. On the other hand, in inorganic turbid lakes, the organic carbon derived from terrestrial sources would dominate the organic matter, which is considered a poor substrate to bacteria because of its chemical recalcitrance (Salcher, 2014). Probably, these different sources of organic matter would influence the differences in bacteria abundances in the three shallow lakes here studied.

When comparing bacterioperiphyton and bacterioplankton composition in each shallow lake, we found differences between both communities, i.e., in El Burro a more important presence of Gammaproteobacteria in the bacterioperiphyton than in the bacterioplankton. Pelagic and benthic habitats could differ considerably regarding nutrient and light availability. Unlike plankton, biofilms form a great diversity of complex structures that allow them to grow under a diverse range of conditions. One of these structures are water channels which are present in the periphytic matrix and may increase the supply of nutrients to the cells (Stoodley et al., 2000), thus favouring their growth under critical conditions.

The hybridization percentages of EUB II-III obtained in our study varied depending on the lake and the bacterial community. The clear vegetated lake exhibited higher values of hybridization than the turbid ones. It should be noted that the hybridization efficiency could vary according to the quantity of ribosomes present in the target cell (Pernthaler et al., 2002). In the present study, the hybridization percentage of Eubacteria was always higher in bacterioperiphyton than in bacterioplankton. A similar difference was observed by Araya et al. (2003), who argued that this may be related to the higher activity of 
the cells belonging to biofilm in comparison with the planktonic bacteria.

It should be noted that the probes selected cover large groups as well as several lineages within them (Newton et al., 2011). Since this general probes could be masking a great variability of lineages, similar studies should be conducted using more specific probes to detect possible differences that may have been overlooked. Another factor that should not be discarded is the effect of the use of artificial substrata on bacterioperiphyton analyzes. In the first states of the conformation of the adhering community, the presence of organic molecules over the colonized surface is of great importance since bacteria do not adhere to a clean substrate (Busscher \& Van der Mei, 2000). This may affect the bacterioperiphyton community developed over artificial or natural substrata (e.g., macrophytes, rocks, sediments). However, artificial substrata allow quantifying and manipulating the attached community, which would be almost impossible by means of natural substrata.

Our study suggest that the lake regime (clear and turbid) influence the bacterial structure of planktonic and periphytic communities. This influence was mainly reflected in the subdominant bacterial groups in each lake type. Moreover, we found that the bacterial composition differed between the pelagic and the attached communities.

\section{ACKNOWLEDGMENTS}

We thank to the owners of the farms for allowing us to have access to the lakes studied and to the members of Laboratorio de Ecología y Fotobiología Acuática from IIB-INTECH (Chascomús, Buenos Aires, Argentina) where part of the CARD-FISH technique was performed. We also thank to two anonymous reviewers and to the editor for their valuable suggestions on the manuscript. This research was supported by a grant of the University of Buenos Aires (UBACyT X838) and PAMPA $^{2}$ Project (CONICET).

\section{REFERENCES}

Allende, L., G. Tell, H. Zagarese, A. Torremorell, G. Pérez, J. Bustingorry, R. Escaray \& I. Izaguirre. 2009. Phytoplankton and primary production in clearvegetated, inorganic-turbid, and algal-turbid shallow lakes from the pampa plain (Argentina). Hydrobiologia, 624: 45-60.

Alonso-Sáez, L. \& J. Gasol. 2007. Seasonal variations in the contributions of different bacterial groups to the uptake of low-molecular-weight compounds in north- western Mediterranean coastal waters. Appl. Environ. Microbiol., 73: 3528-3535.

Amann, R.I. \& B.M. Fuchs. 2008. Single-cell identification in microbial communities by improved fluorescence in situ hybridization techniques. Nat. Rev. Microbiol., 6: 339-348.

Amann, R.I., L. Krumholz \& D.A. Stahl. 1990. Fluorescent-oligonucleotide probing of whole cells for determinative, phylogenetic and environmental studies in microbiology. J. Bacteriol., 172: 762-770.

Amann, R.I., W. Ludwig \& K.-H. Schleifer. 1995. Phylogenetic identification and in situ detection of individual microbial cells without cultivation. Microbiol. Rev., 59: 143-169.

American Public Health Association (APHA). 2005. Standard methods for the examination of water and wastewaters. Washington DC, $1217 \mathrm{pp}$.

Araya, R., K. Tani, T. Takagi, N. Yamaguchi \& M. Nasu. 2003. Bacterial activity and community composition in stream water and biofilm from an urban river determined by fluorescent in situ hybridization and DGGE analysis. FEMS Microbiol. Ecol., 43: 111-119.

Bertoni, R., C. Callieri, E. Balseiro \& B. Modenutti. 2008. Susceptibility of bacterioplankton to nutrient enrichment of oligotrophic and ultraoligotrophic lake waters. J. Limnol., 67: 120-127.

Brinson, M.M. 2004. Niveles extremos de variación de patrones y procesos en humedales. In: A.I. Malvárez \& R. Bó (eds.). Documentos del Curso-Taller: bases ecológicas para la clasificación e inventario de humedales en Argentina. Buenos Aires, pp. 19-24.

Busscher, H.J. \& H.C. Van der Mei. 2000. Initial microbial adhesion events: mechanisms and implications. In: D.G. Allinson, P. Gilbert, H.M. Lappin-Scott \& M. Wilson (eds.). Community structure and co-operation in biofilms. Society for General Microbiology, University Press, Cambridge, pp. 25-36.

Daims, H., A. Brühl, R. Amann, K.-H. Schleifer \& M. Wagner. 1999. The domain-specific probe EUB 338 is insufficient for the detection of all Bacteria: development and evaluation of a more comprehensive probe set. Syst. Appl. Microbiol., 22: 434-444.

De Figueiredo, D.R., M.J. Pereira \& A. Correia. 2010. Seasonal modulation of bacterioplankton community at a temperate eutrophic shallow lake. World J. Microbiol. Biot., 26: 1067-1077.

Glöckner, F.O., B.M. Fuchs \& R. Amann. 1999. Bacterioplankton compositions of lakes and oceans: a first comparison based on fluorescence in situ hybridization. Appl. Environ. Microbiol., 65: 3721-3726.

Glöckner, F.O., E. Zaichickov, N. Belkova, L. Dessinova, J. Pernthaler \& R. Amann. 2000. Comparative 16S rRNA analysis of lake bacterioplankton reveals globally distributed phylogenetic clusters including an 
abundant group of Actinobacteria. Appl. Environ. Microbiol., 66: 5053-5065.

Hempel, M., M. Blume, I. Blindow \& E.M. Gross. 2008. Epiphytic bacterial community composition on two common submerged macrophytes in brackish water and freshwater. BMC Microbiol., 8: 58.

Izaguirre, I., L. Allende, R. Escaray, J. Bustingorry, G. Pérez \& G. Tell. 2012. Comparison of morphofunctional phytoplankton classifications in humanimpacted shallow lakes with different stable states. Hydrobiologia, 698: 203-216.

Lemarchand, C., L. Jardillier, J.-F. Carrias, M. Richardot, D. Debroas, T. Sime-Ngando \& C. Amblard. 2006. Community composition and activity of prokaryotes associated to detrital particles in two contrasting lake ecosystems. FEMS Microbiol. Ecol., 57: 442-451.

Llames, M.E., P.A. del Giorgio, H. Zagarese, M. Ferraro \& I. Izaguirre. 2013. Alternative states drive the patterns in the bacterioplankton composition in shallow Pampean lakes (Argentina). Environ. Microbiol. Rep., 5: 310-321.

Logue, J.B., H. Bürgmann \& C.T. Robinson. 2008. Progress in the ecological genetics and biodiversity of freshwater bacteria. BioScience, 58: 103-113.

Lorenzen, C.J. 1967. Determination of chlorophyll and pheopigments: spectrophotometric equations. Limnol. Oceanogr., 12: 343-346.

Lupini, G., L. Proia, M. Di Maio, S. Amalfitano \& S. Fazi. 2011. CARD-FISH and confocal laser scanner microscopy to assess successional changes of the bacterial community in freshwater biofilms. J. Microbiol. Meth., 86: 248-251.

Manz, W., R. Amann, W. Ludwig, M. Wagner \& K.-H. Schleifer. 1992. Phylogenetic oligodeoxynuleotide probes for the major subclasses of proteobacteria: problems and solutions. Syst. Appl. Microbiol., 15: 593-600.

Manz, W., R. Amann, W. Ludwig, M. Vancanney \& K.H. Schleifer. 1996. Application of a suite of 16S rRNA -specific oligonucleotide probes designed to investigate bacteria of the phylum cytophagaflavobacter-bacteroides in natural environment. Microbiology, 142: 1097-1106.

Marker, A.F.H., A. Nusch, H. Rai \& B. Riemann. 1980. The measurement of photosynthetic pigments in freshwater and standardization of methods: conclusions and recommendations. Arch. Hydrobiol. Beihefte Ergeb. Limnol., 14: 91-106.

Methé, B.A., W.D. Hiorns \& P.Z. Zehr. 1998. Contrasts between marine and freshwater bacterial community composition: analyzes of communities in Lake George and six other Adirondack lakes. Limnol. Oceanogr., 43: 368-374.

Newton, R.J., S.E. Jones, A. Eiler, K.D. McMahon \& S. Bertilsson. 2011. A guide to the natural history of freshwater lake bacteria. Microbiol. Mol. Biol. Rev., 75: 14-49

Pérez, G.L., A. Torremorell, J. Bustingorry, R. Escaray, P. Pérez, M. Diéguez \& H. Zagarese. 2010. Optical characteristics of shallow lakes from the Pampa and Patagonia regions of Argentina. Limnologica, 40: 3039.

Pernthaler, A., J. Pernthaler \& R. Amann. 2004. Sensitive multi-color fluorescence in situ hybridization for the identification of enviromental microorganisms. Molec. Microb. Ecol. Manage., 2: 771-726.

Pernthaler, J., F.O. Glöckner, W. Schönhuber \& R. Amann. 2001. Fluorescence in situ hybridization (FISH) with rRNA-targeted oligonucleotide probes. Method. Microbiol., 30: 207-226.

Pernthaler, A., C.M. Preston, J. Pernthaler, E.F. DeLong \& R. Amann. 2002. Comparison of fluorescently labeled oligonucleotide and polynucleotide probes for the detection of pelagic marine bacteria and archaea. Appl. Environ. Microbiol., 68: 661-667.

Pohlon, E., J. Marxsen \& K. Küsel. 2010. Pioneering bacterial and algal communities and potential extracellular enzyme activities of stream biofilms. FEMS Microbiol. Ecol., 71: 364-373.

Posch, T., B. Mindl, K. Horňák, J. Jezbera, M.M. Salcher, B. Sattler, B. Sonntag, J. Vrba \& K. Šimek. 2007. Biomass reallocation within freshwater bacterioplankton induced by manipulating phosphorus availability and grazing. Aquat. Microb. Ecol., 49: 223-232.

Quirós, R., A.M. Renella, M.B. Boveri, J. Rosso \& A. Sosnovsky. 2002. Factores que afectan la estructura y el funcionamiento de las lagunas pampeanas. Ecol. Aust., 12: 175-185.

Quirós, R., M.B. Boveri, C.A. Petrachi, A.M. Renella, J.J. Rosso, A. Sosnovsky \& H.T. Von Bernard. 2006. Los efectos de la agriculturización del humedal pampeano sobre la eutrofización de sus lagunas. In: J.G.T. Tundisi, C. Matsumura-Tundisi \& G. Sidagis (eds.). Eutrofização na América do Sul: causas, conseqüências e tecnologias de gerenciamento e controle, São Carlo, pp. 1-16.

Salcher, M.M., J. Pernthaler \& T. Posch. 2011. Seasonal bloom dynamics and ecophysiology of the freshwater sister clade of SAR11 bacteria "that rule the waves" (LD12). ISME J., 5: 1242-1252.

Salcher, M.M. 2014. Same same but different: ecological niche partitioning of planktonic freshwater prokaryotes. J. Limnol., 73: 74-87. 
Sánchez, M.L., H. Pizarro, G. Tell \& I. Izaguirre. 2010. Relative importance of periphyton and phytoplankton in turbid and clear vegetated shallow lakes from the Pampa Plain (Argentina): a comparative experimental study. Hydrobiologia, 646: 271-280.

Sánchez, M.L., G.L. Pérez, I. Izaguirre \& H. Pizarro. 2013. Influence of underwater light climate on periphyton and phytoplankton communities in shallow lakes from the Pampa plain (Argentina) with contrasting steady states. J. Limnol., 72: 62-78.

Scheffer, M. 2009. Critical transitions in nature and society. Princeton University, Oxford, 384 pp.

Scheffer, M. 1998. Ecology of shallow lakes. Chapman \& Hall, London, $357 \mathrm{pp}$.

Scheffer, M., S.H. Hosper, M.-L. Meijer, B. Moss \& E. Jeppesen. 1993. Alternative equilibria in shallow lakes. TREE, 8: 275-279.

Sekar, R., A. Pernthaler, J. Pernthaler, F. Warnecke, T. Posch \& R. Amann. 2003. An improved protocol for the quantification of freshwater actinobacteria by fluorescence in situ hybridization. Appl. Environ. Microbiol., 69: 2928-2935.

Šimek, K., K. Hornák, J. Jezbera, J. Nedoma, J. Vrba, V. Straskrábová, M. Macek, J.R. Dolan \& M.W. Hahn. 2006. Maximum growth rates and possible life strategies of different bacterioplankton groups in relation to phosphorus availability in a freshwater reservoir. Environ. Microbiol., 8: 1613-1624.

Silvoso, J., I. Izaguirre \& L. Allende. 2010. Picoplankton structure in clear and turbid eutrophic shallow lakes: a seasonal study. Limnologica, 41: 181-190.

Stoodley, P., L. Hall-Stoodley, J.D. Boyle, F. Jørgensen \& H.M. Lappin-Scott. 2000. Environmental and genetic factors influencing biofilm structure. In: D.G. Allinson, P. Gilbert, H.M. Lappin-Scott \& M. Wilson (eds.). Community structure and co-operation in biofilms. Society for General Microbiology, University Press, Cambridge, pp. 53-64.

Received: 10 June 2014; Accepted: 10 May 2015
Ter Braak, C.J.F. 1986. Canonical correspondence analysis: a new eigenvector technique for multivariate direct gradient analysis. Ecology, 67: 1167-1179.

Ter Braak, C.J.F \& P. Smilauer. 2002. CANOCO reference manual and CanoDraw for Windows user's guide: software for canonical community ordination (version 4.5). Micro-computer Power, Ithaca, New York, 500 pp.

Urdea, M.S., B.D. Warner, J.A. Running, M. Stempien, J. Clyne \& T. Horn. 1988. A comparison of nonradioisotopic hybridization assay methods using fluorescent, chemiluminescent and enzyme labeled synthetic oligodeoxyribonucleotide probes. Nucleic Acids Res., 16: 4937-4956.

Van der Gucht, K., T. Vandekerckhove, N. Vloemans, S. Cousin, K. Muylaert, K. Sabbe, M. Gillis S. Declerk, L. De Meester \& W. Vyverman. 2005. Characterization of bacterial communities in four freshwater lakes differing in nutrient load and food web structure. FEMS Microbiol. Ecol., 53: 205-220.

Velji, M.I. \& L.J. Albright. 1993. Improved sample preparation for enumeration of aggregated aquatic substrate bacteria. In: P.F. Kemp, B.F. Sherr, E. Sherr \& J.J. Cole (eds.). Handbook of methods in aquatic microbial ecology. Lewis Publishers, Florida, pp.139142.

Villar, C., L. de Cabo, P. Vaithiyanathan \& C. Bonetto. 1998. River-floodplain interactions: nutrient concentrations in the Lower Paraná River. Arch. Hydrobiol., 142: 433-450.

Warnecke, F., R. Sommaruga, R. Sekar, J.S. Hofer \& J. Pernthaler. 2005. Abundances, identity, and growth state of actinobacteria in mountain lakes of different UV transparency. Appl. Environ. Microbiol., 71: 55515559. 